ENTREPRENEURSHIP AND SUSTAINABILITY ISSUES

ISSN 2345-0282 (online) http://jssidoi.org/jesi/

2020 Volume 8 Number 2 (December)

http://doi.org/10.9770/jesi.2020.8.2(13)
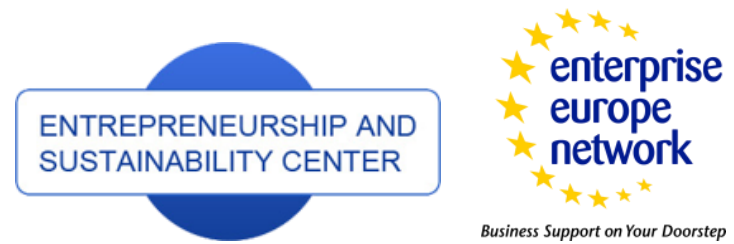

Business Support on Your Doorstep
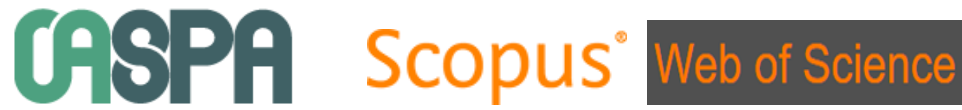

http://jssidoi.org/esc/home

\begin{abstract}
Clarivate
Analytics
\section{DEVELOPMENT OF ENTREPRENEURSHIP AND FORMS OF SELF-EMPLOYMENT IN THE INNOVATIVE SECTORS OF THE ECONOMY} \author{
Marzhan Daurbayeva ${ }^{5}$, Madina Aitkazina ${ }^{6}$
}

Bakyt Beknazarov ${ }^{1}$, Roza Niyazbekova ${ }^{2}$, Ussen Amirseitov ${ }^{3}$, Aiganym Kokenova ${ }^{4}$,

\author{
1,2,5 M. Auezov South Kazakhstan State University, Tauke Khan Avenue, 5, Shymkent, 160012, Kazakhstan \\ ${ }^{3}$ Silkway International University, Tokaev Street 27 "A”, Shymkent, 160011, Kazakhstan \\ ${ }^{6}$ Narxoz University, Zhandosov Street, 55, Almaty, 050035, Kazakhstan
}

${ }^{4}$ International Humanitarian and Technical University, Baitursynov Street, 80a, Shymkent, 160021, Kazakhstan
\end{abstract}

Received 18 February 2020, accepted 12 August 2020, published 30 December 2020

\begin{abstract}
The goal of this study is to identify the problems and barriers that impede the growth and development of small and medium innovative enterprises (innovative SMEs) and suggest ways to overcome them. The main methods of the study include a survey of the founders of innovative companies from Russia and Belarus, as well as expert interviews. The study involved both mature companies and startups. The results of the study indicate that most innovative companies lack personnel with the necessary education and experience. At the same time, the number of researchers is decreasing, and external part-timers are being involved to carry out the research. The innovative activities in the countries under study remain low. The main barriers to the growth of this indicator include the lack of financial resources, the difficulties with raising external financing, as well as the shortage of the professional personnel. A set of measures to financially encourage researchers and tax incentives for innovative entrepreneurship are proposed as the main incentives to increasing the innovative activities.
\end{abstract}

Keywords: innovation, R\&D; freelance; innovative activities; startup; small enterprises

Reference to this paper should be made as follows: Beknazarov, B., Niyazbekova, R., Amirseitov, U., Kokenova, A., Daurbayeva, M., Aitkazina, M. 2020. Development of entrepreneurship and forms of self-employment in the innovative sectors of the economy. Entrepreneurship and Sustainability Issues, 8(2), 209-228. http://doi.org/10.9770/jesi.2020.8.2(13)

JEL Codes: M2, M5 


\section{ENTREPRENEURSHIP AND SUSTAINABILITY ISSUES}

ISSN 2345-0282 (online) http://jssidoi.org/jesi/

2020 Volume 8 Number 2 (December)

http://doi.org/10.9770/jesi.2020.8.2(13)

\section{Introduction}

There has been an increase in investment in innovation worldwide in recent years; the use of intellectual property has reached record levels (The Global Innovation Index 2019). According to Eurostat, R\&D expenses increased by $53.5 \%$ in the EU member states, by $65 \%$ in the US, and almost 2.9 times in South Korea for $2009-2017$ (Eurostat, 2020a).

Most of the global $R \& D$ expenses were in the business sector. The share of private sector investment in $R \& D$ amounted to $61.2 \%$ of the total R\&D expenses in the EU member states, $73 \%$ in the US, $78.8 \%$ in Japan, and $79.4 \%$ in South Korea in 2017.

SMEs have traditionally been recognized as the driving force behind growth and innovation in the economy. For example, the business sector of the EU member states (27) accounts for $66.4 \%$ of the total domestic R\&D expenses (Eurostat, 2020b). The European business sector employs $51.3 \%$ of the total R\&D personnel (Eurostat, 2020c).

Despite the relatively small R\&D budget, a third of the annual patent applications at the European Patent Office are filed by innovative SMEs (Patent Index 2019).

However, the level of innovative activities of SMEs in middle-income countries, including Russia, Kazakhstan, and Belarus, is significantly lower than that in high-income countries. For example, about $72 \%$ of the total number of SMEs are introducing a new product or business process in Sweden, $71 \%$ in Norway, $67 \%$ in Belgium, $64 \%$ in the US, and $62 \%$ in Germany. This indicator is about $5 \%$ in the Russian Federation (OECD, 2020), $7.2 \%$ in Kazakhstan (On the innovative activities of enterprises in the Republic of Kazakhstan, 2018), and $4.3 \%$ in the Republic of Belarus (National Statistical Committee of the Republic of Belarus, 2018).

Small businesses trying to market the innovative technology products and services often face unique problems and barriers that large multinational corporations do not face, and they often need to overcome such barriers with fewer resources (Bushueva, et. al. 2020). The shortage of human resources is a particular problem for SMEs, because the number of specialists who are knowledge holders and have the necessary competencies and experience in innovations is extremely limited (Dudin et al. 2020).

Encouraging employment in the innovative sector and encouraging youth to start their own businesses and to create breakthrough technology become important measures to expand the innovative activities of SMEs (Muraya, et. al. 2019). Significant potential for attracting personnel to innovative areas lies in the development of new forms of employment. For example, such forms of employment as freelancing, self-employment with hired workers, etc. are becoming more common in European countries (Danilina, et. al. 2020)

The problems faced by individual entrepreneurs and fast-growing SMEs when trying to commercialize an innovative product or service have been examined in this study.

The hypothesis has been formulated during the study that the encouragement of the forms of self-employment and the creation of new SMEs in research and innovation are flexible tools for the growth of innovative activities and are vital for the economic growth of countries with developing economies. 


\section{Literature review}

Innovations represent the introduction of a new or significantly improved product (goods or services), a process, a new marketing method, or a new organizational method in business practice, workplace organization, or external relations (Mohd Rosli \& Syamsuriana Sidek 2013).

Many studies confirm the positive impact of innovation on business performance (Galindo \& Méndez-Picazo 2013; Saiz-Álvarez, et. al. 2013; Lucchese \& Pianta 2012; Wang et al. 2019; Kumar, 2019; Laužikas, Miliūtė, 2020).

It is important to note that new products and services must be commercialized, i.e., marketed in order to be considered innovations (Klyver, et. al. 2012). Innovative entrepreneurship is one of the main means by which new knowledge and technology are transformed into economic and social benefits (Baumol 2010).

A significant share of the works in the contemporary scientific literature is devoted to studying the degree of influence of innovative entrepreneurship on the socioeconomic development of a country (De la Hoz-Rosales, et. al. 2019; Acs, et. al. 2012; Aparicio, et. al. 2016; Karshalova, et. al. 2017), the factors that determine innovative behavior and the offer of new products by SMEs (Velilla \& Ortega 2020; Castaño, et. al. 2015), and the innovative entrepreneurial education (Lee, et. al. 2020; Chen, et. al. 2018).

Financing problems (Li, et. al. 2015; Giraudo, et. al. 2019; Bertoni, et. al. 2019; Colombo, et. al. 2013; Giudicic, et. al. 2018), patent protection issues and incentives for investment in innovative startups (Cumming, et. al. 2017; Grilli, et. al. 2018), and government support measures (Ruchkina, et. al. 2017; Mas-Tur \& Simón 2015; Grilli, et. al. 2018) for young innovative companies are some of the relevant areas of research.

The development of innovative entrepreneurship and the digital transformation of the society have led to the emergence of new forms of work that are significantly different from standard labor relations. Certain aspects of the development of new employment forms in SMEs are reviewed in the works of Orlova (2017), Kirchhoff (2007), Serrano (2010), Alois (2020), and others.

The studies indicate that the forms of employment based on open and temporary contracts, freelancers, and selfemployment with hired workers are gaining popularity in the world now (Eurofound, 2018).

The study of the scientific literature reveals that there have been relatively few empirical data around the world until recently to answer the question about the participation of SMEs and self-employed workers in the development of an innovative economy. The early studies relied on data from officially registered companies, leaving informal forms of employment, which in many countries were the largest source of employment, out of the picture.

As such, the problems of entrepreneurship development and self-employment in innovative sectors of the economy remain poorly explored. 


\section{Methods}

The trends based on the opinions and intentions of the population and the heads of SMEs, describing the dynamics and scale of innovative processes, factors constraining innovative activities, and barriers to the development of innovative entrepreneurship have been revealed in the course of a specially organized market observation.

The key questions addressed in this study are the following: how innovative are SMEs in various sectors and by international standards? Why and when do SMEs invest in research and innovation? Where are the barriers and potential for research and innovation?

A methodology was developed to accomplish these tasks, which included the collection and analysis of primary qualitative and quantitative data. A random sample was made for the survey to ensure that the opinions expressed during the survey were representative.

The goals of sampling included maximizing the number of responses and ensuring the representativeness of the population and SME enterprises. The survey was conducted online.

The experts were selected based on the professional status of a person. They included people whose professional activities were related to the relationship between the institute of entrepreneurship for more than two years. The sample included two groups of respondents: 516 respondents from the population of three countries in the postSoviet space (Kazakhstan, Russia, and Belarus) and 244 SMEs engaged in innovative activities.

During the study, the SMEs were asked to evaluate their satisfaction with various aspects of their development. The evaluations had to be given on a 10-point scale, where 1 meant absolute dissatisfaction, 10 meant absolute satisfaction, and 0 meant that this indicator was not significant for the company development or difficult to evaluate.

In addition, the respondents could choose multiple answers for some questions. The substantiated answers were obtained from the generalized comments of the respondents.

All participants were warned about the purpose of the survey and that the study organizers were planning to publish the generalized results of the study in the future. All expert quotes were provided in the article anonymously. The experts chose the language they answered the question (Russian or English) themselves.

\section{Results}

The average age of the SMEs participating in the survey is 2.5 years. The main share is made up of the companies created less than one year ago (Figure 1). 


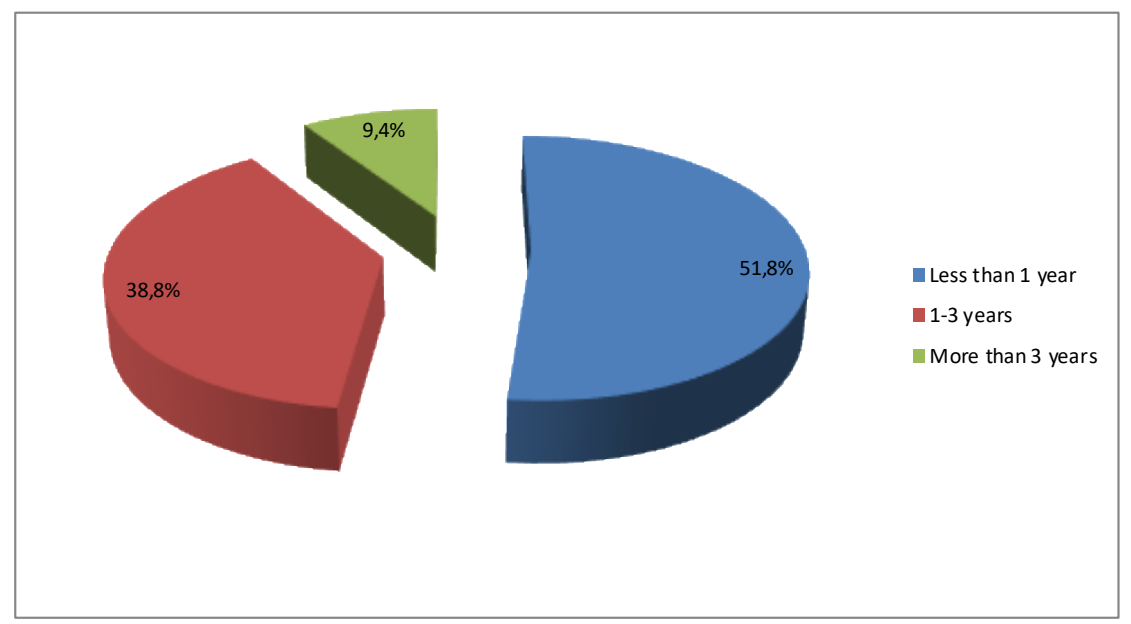

Figure 1. Age structure of the SMEs participating in the survey, $\%$ of the total number of respondents

The largest share of the enterprises surveyed $(52.7 \%)$ are research organizations and higher education organizations ( $22.3 \%$ of the respondents). The companies surveyed in the three countries do not have significant differences, depending on the type of business (Figure 2).

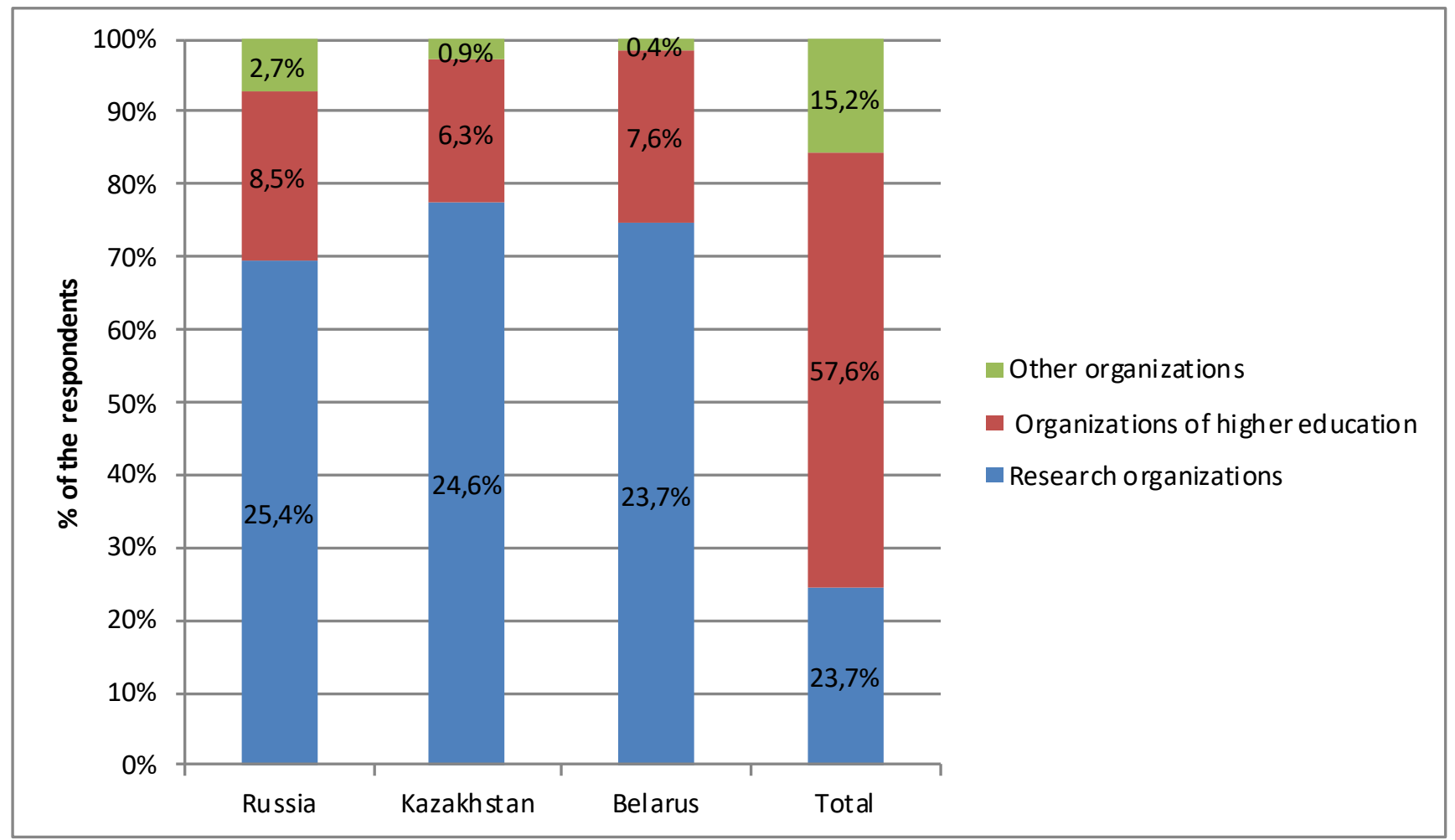

Figure 2. Structure of the innovative SMEs, \% of the total number of respondents 
The areas of activity of the SMEs participating in the survey are quite diverse. For example, almost half of the experts surveyed represent the telecommunications, media, and technology sector (Figure 3). About $22.8 \%$ of the surveyed companies work in the biotechnology and pharmaceutical sectors, $16.1 \%$ of the companies participating in the survey create technological solutions for specific industries, $10.3 \%$ create innovations in instrument engineering, and the remaining $4 \%$ of the innovative companies specialize on the developments for the consumer sector and education.

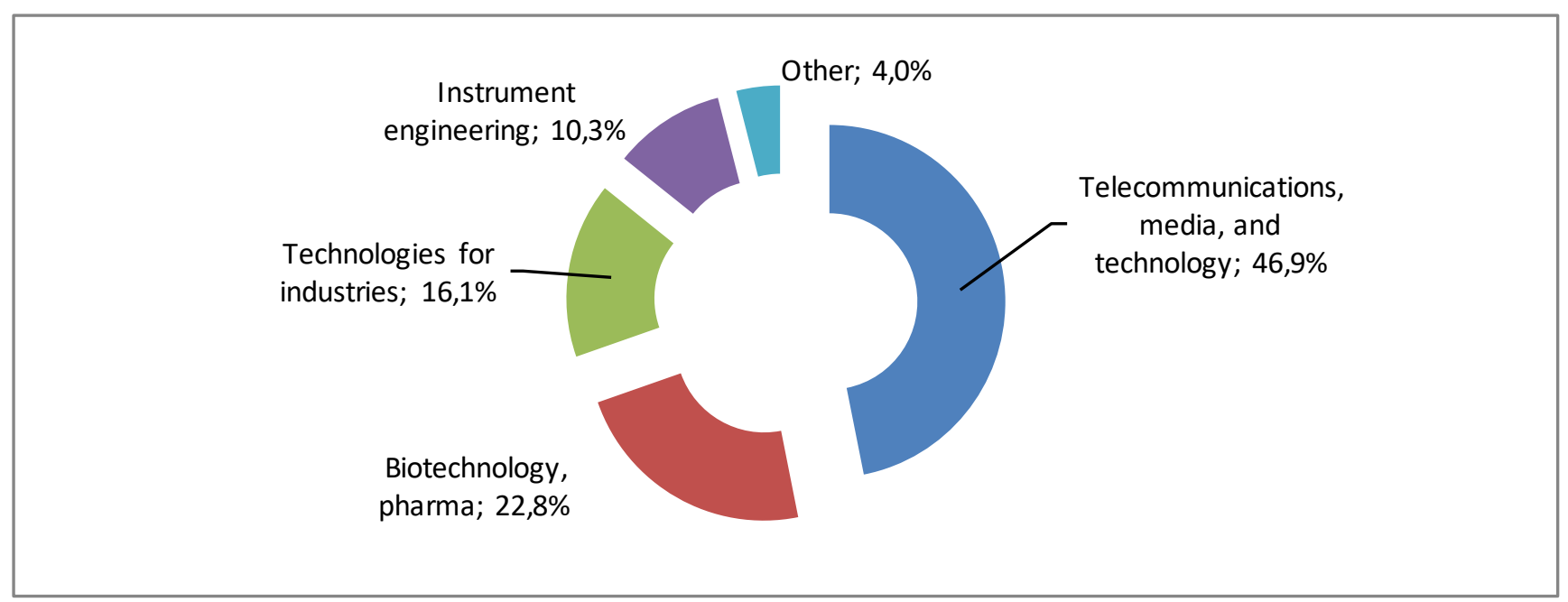

Figure 3. Structure of the respondents by field of activities, \%

The vast majority of the companies participating in the survey are mature. At the same time, $10.7 \%$ of the experts noted that their company was at the stage of the stable product monetization. Most of the companies surveyed are in the business scaling stage, i.e., according to experts, their enterprise is able to cope with an increase in the volume of work or output in a cost-effective and reasonable way at the current stage of development (Figure 4).

The share of mature innovative enterprises is at approximately the same level and amounts to $22.3 \%$ in Russia and $21 \%$ in Kazakhstan. This indicator is slightly lower in Belarus and amounts to $16.9 \%$ of the total number of innovative companies. 


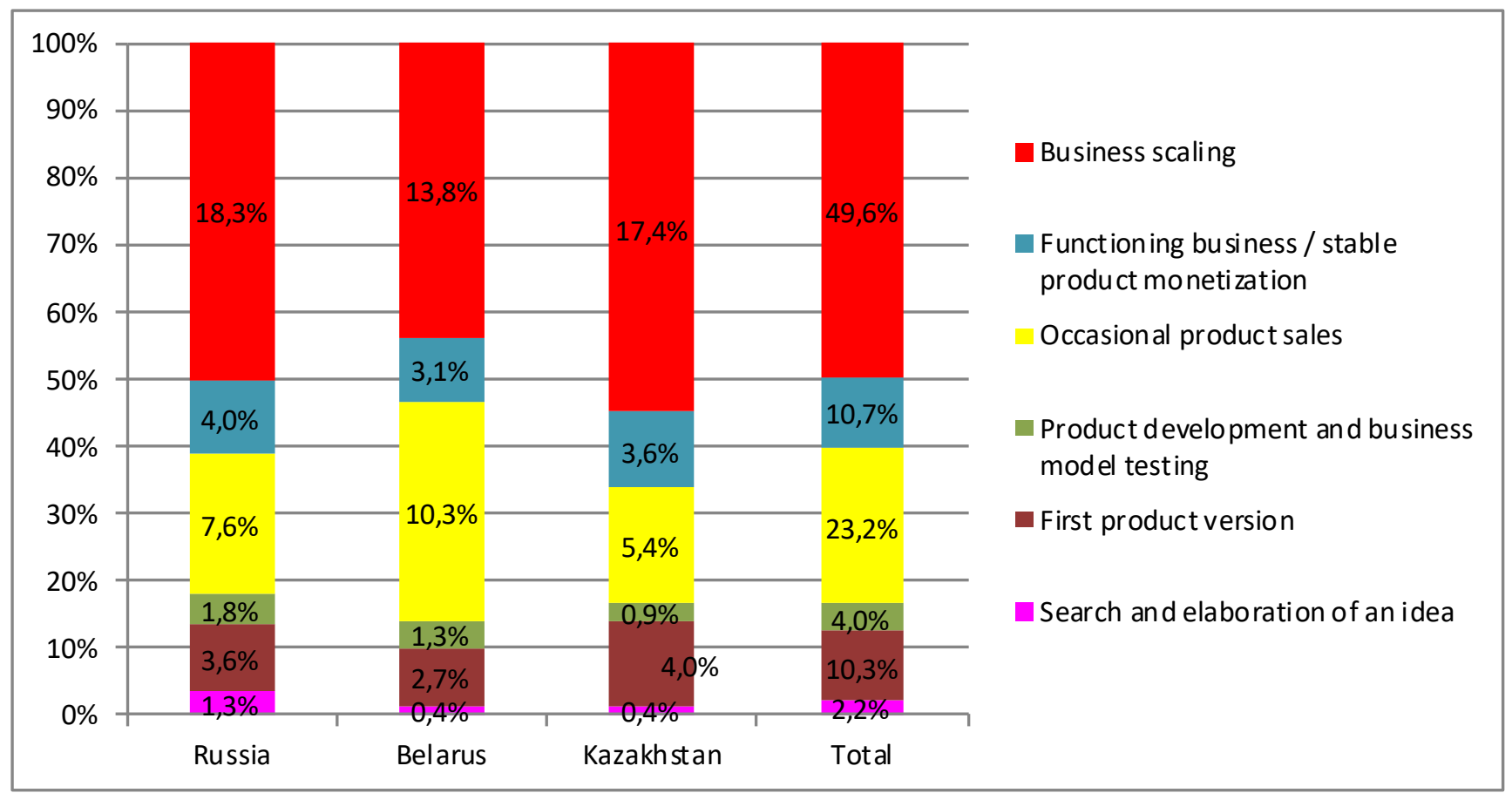

Figure 4. Structure of the respondents by the stage of development of innovative activities, $\%$ of the respondents

About $17 \%$ of the companies surveyed are currently at the startup stage and have no revenue, while the annual revenue of $27 \%$ of the companies is less than USD 15,000. The distribution of respondents by average annual revenue is provided in Figure 5.

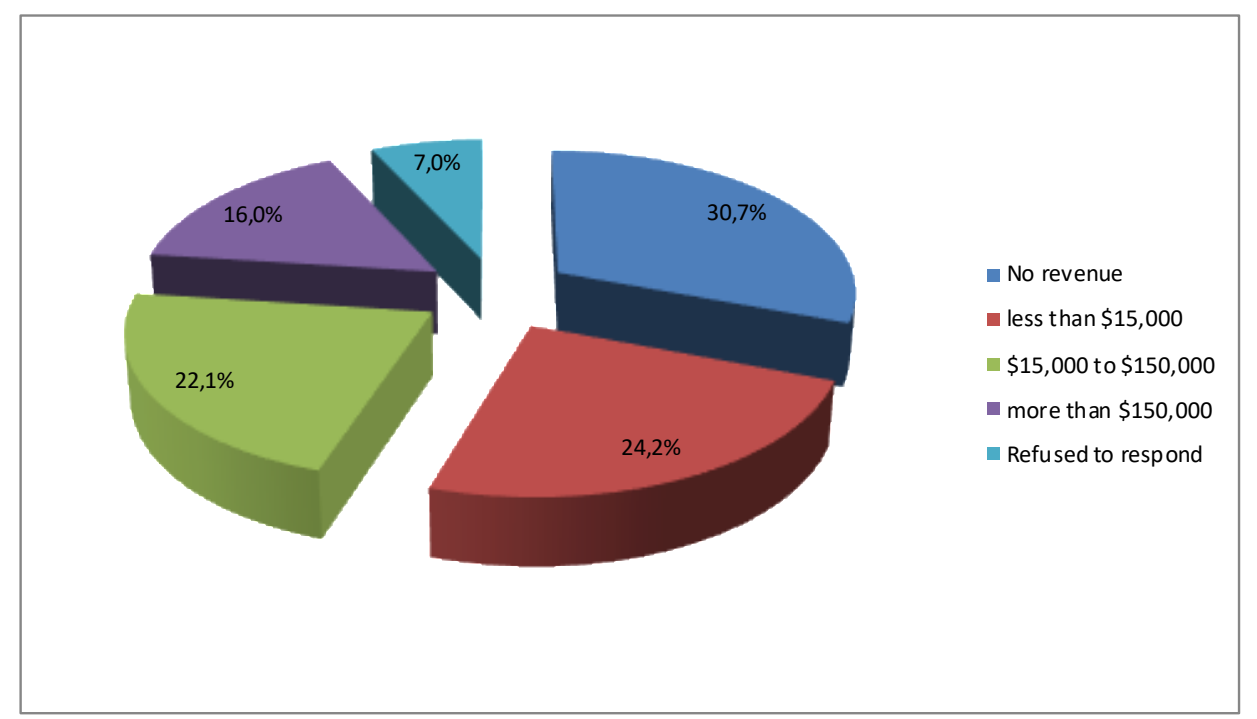

Figure 5. Distribution of the respondents by annual revenue for the previous year, $\%$ of the respondents 
The experts were asked to evaluate the degree of their innovations during the study. For example, the majority $(43.3 \%)$ of the companies say that their product is an improvement in innovation. More than a third of the companies surveyed $(37.9 \%)$ describe their products as having advantages and disadvantages over peers, but not being significantly better. Radical innovations are created by $17 \%$ of the companies that offer fundamentally new solutions and provide a technological breakthrough. The distribution of the expert opinions on the level of innovation of their products or services is presented in Figure 6.

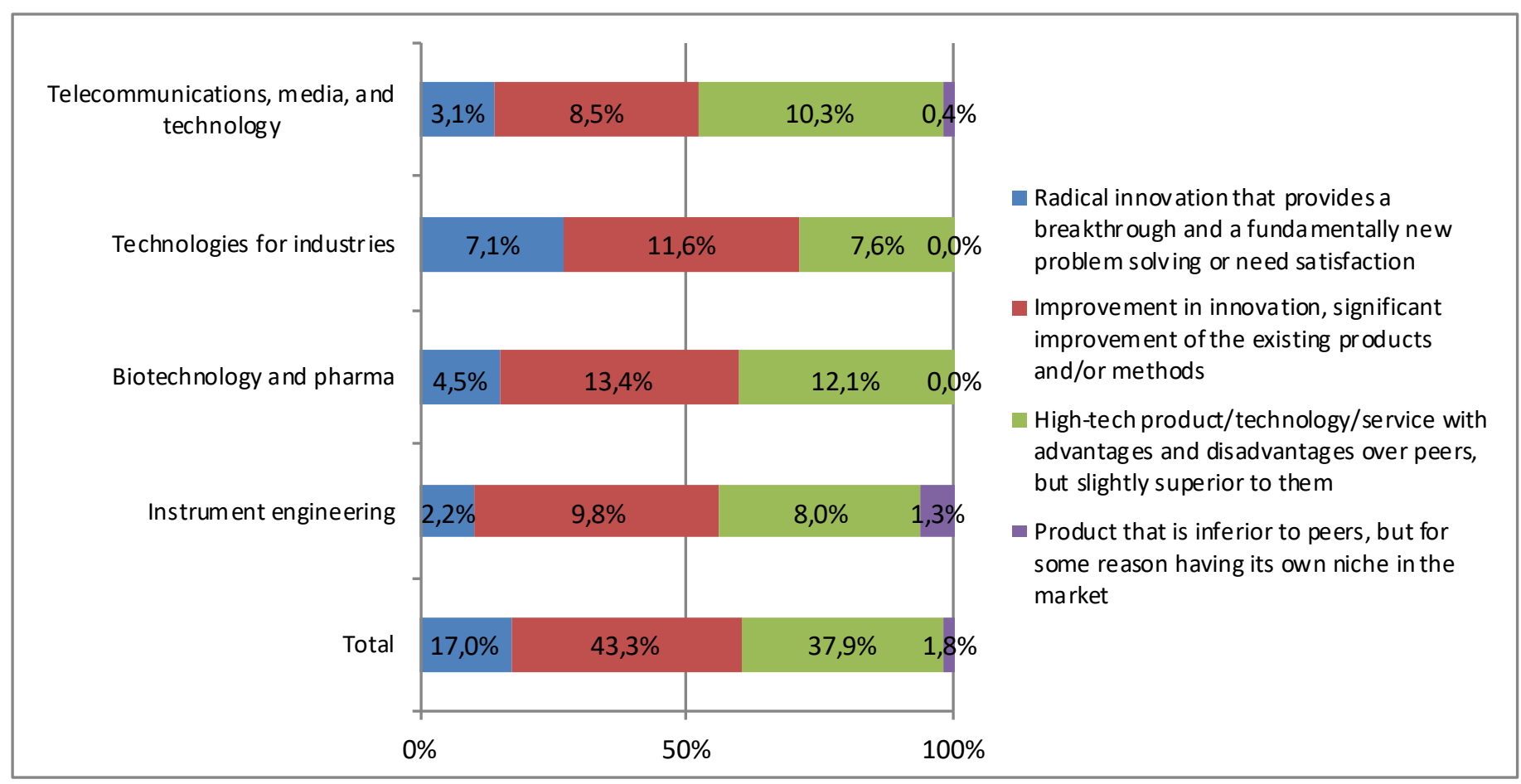

Figure 6. Distribution of the expert opinions on the level of innovation of their products or services

The managers of almost $62 \%$ of the surveyed SMEs indicated an increase in internal spending on R\&D over the previous three years (Figure 7). 


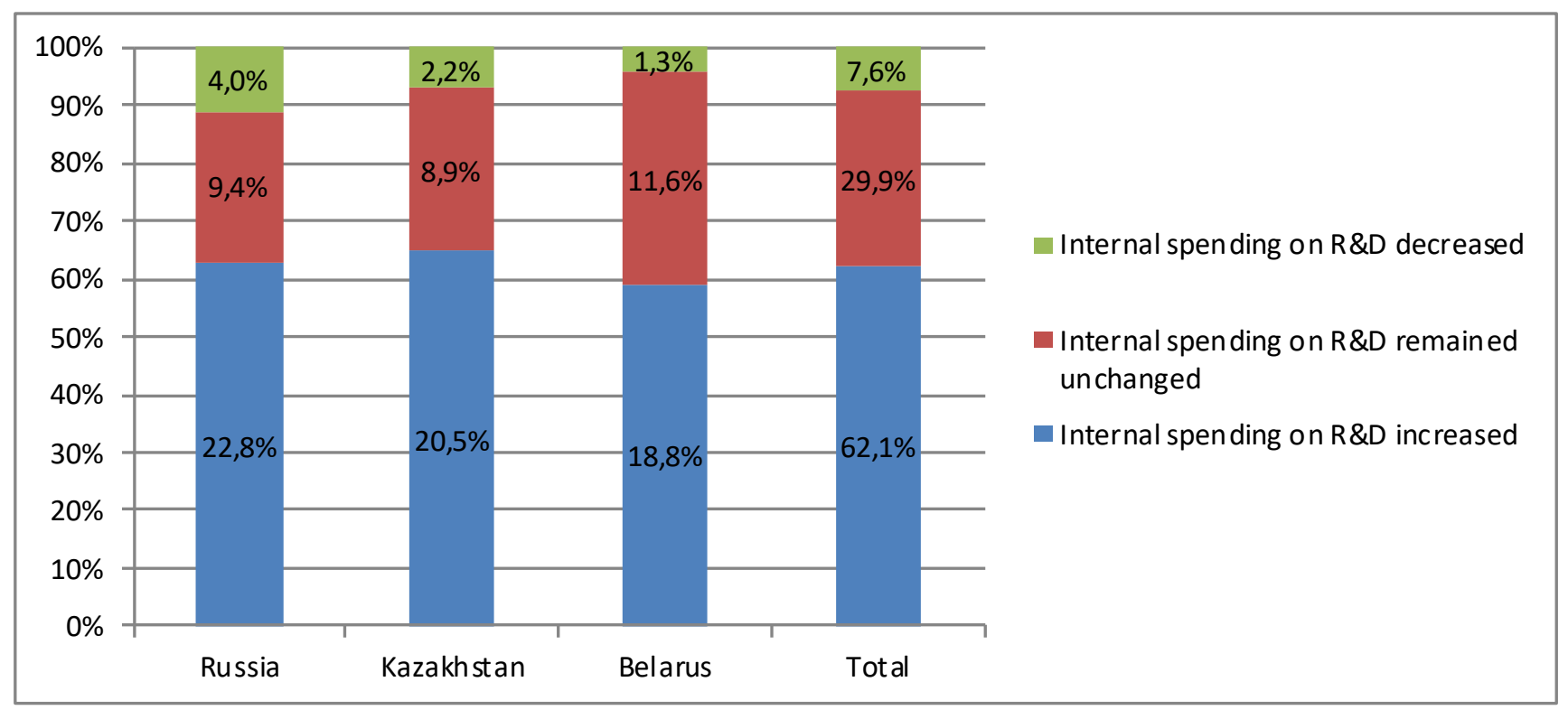

Figure 7. Evaluation of internal spending on $R \& D, \%$ of the respondents

The total number of the personnel in the surveyed organizations was 5,824 people. As such, the average number of employees in innovative SMEs is 26 people.

The results of the study indicate that the companies with up to five full-time employees dominate in the innovative sector today, their largest part being from Russia. Most of the innovative companies from Kazakhstan and Belarus participating in the study have full-time personnel of six to 20 people. Almost every fourth company employs from 21 to 50 people. The distribution of the innovative companies among the three countries by the number of personnel is presented in Figure 8. 


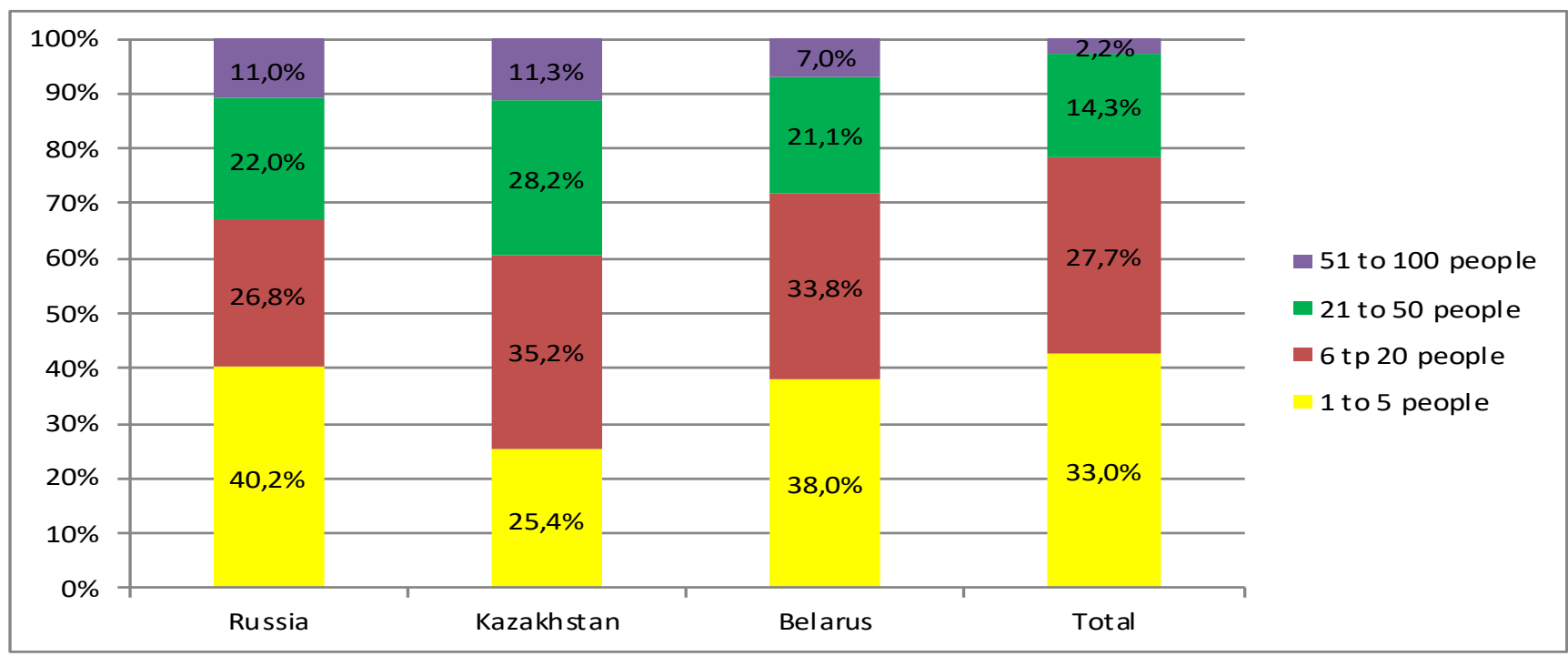

Figure 8. Structure of innovative enterprises by the number of personnel

About $90 \%$ of the respondents say that about half of the personnel in their organizations are researchers. At the same time, 178 respondents ( $79.8 \%$ of the respondents) noted that the number of researchers had decreased over the previous three years, $16.5 \%$ of the experts said that the number of researchers remained the same, and only $3.7 \%$ noted an increase in this indicator. At the same time, similar trends in the decrease in the number of researchers employed by innovative enterprises are observed in Russia, Belarus, and Kazakhstan.

The widespread part-time format is an interesting feature of the labor market in the innovative sector. Almost half of the experts $(48.7 \%$ ) from the SME managers note that they involve external part-timers and researchers under civil law contracts to carry out the research work.

The structure of employment of part-timers in innovative companies in Russia, Belarus, and Kazakhstan is similar: the majority of part-timers work in science and education and in the high-tech industry (Figure 9). 


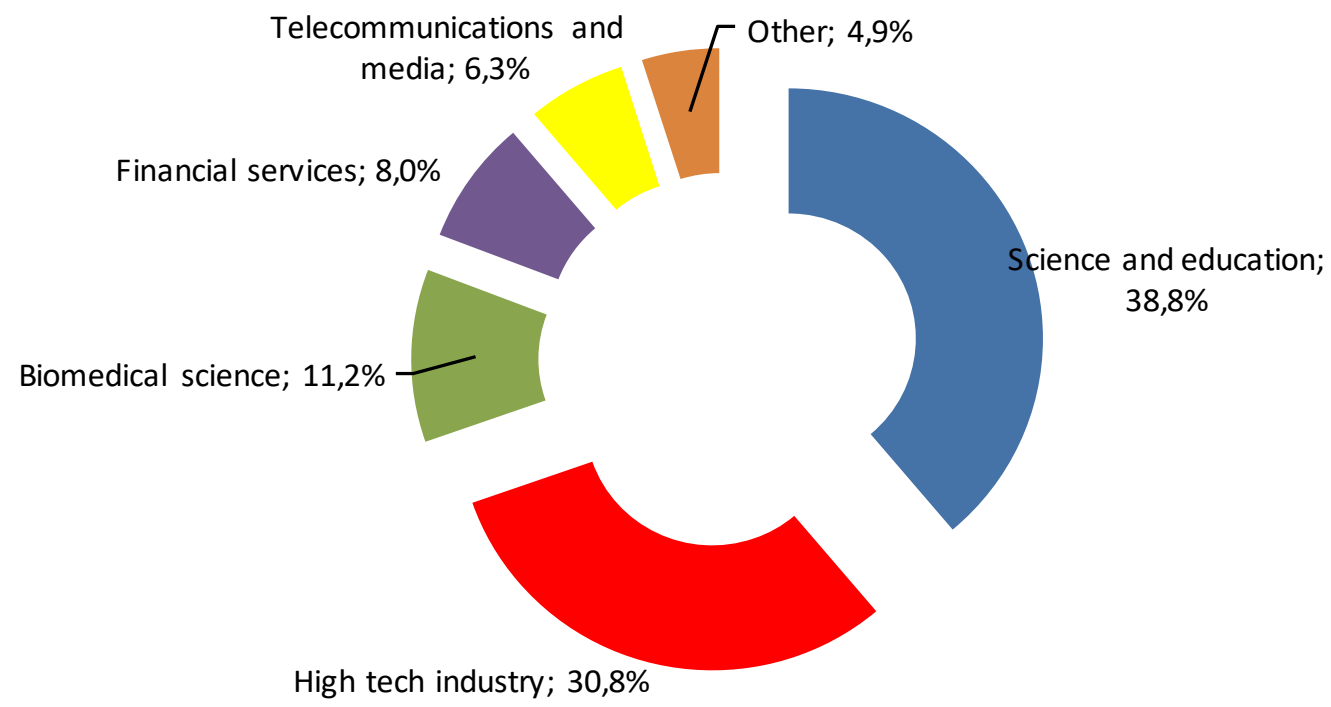

Figure 9. Employment structure of part-timers in innovative companies, $\%$ of the respondents

About $58 \%$ of the experts noted that self-employed workers (freelancers) were involved in the development of individual topics, projects, as well as for the performance of certain works or provision of certain services.

One expert from the high-tech industry noted that $R \& D$ freelancers were involved in research that did not require experiments at scientific laboratories and the use of sophisticated equipment.

According to the expert, it is easier and cheaper to find a qualified freelancer for a one-time project than to adapt a new employee today.

The managers of more than $40 \%$ of the companies noted that independent experts were involved in the implementation of individual projects. The most popular freelance professions involved in innovative projects are "web and mobile design", "development of other software", "development of desktop software", "e-commerce development", "product management", and "Q\&A testing".

It must be noted that, despite the possibility of hiring part-timers in the innovative sector, more than half of the innovative companies $(51.8 \%)$ lack staff with the necessary education and experience.

The companies feel the particularly acute lack of specialists in the following activities: promotion, sales, and PR were indicated by $58.6 \%$ of the innovative companies experiencing staff shortages; research and analytics (52.6 $\%)$; information technology (45.7\%); and strategic management (44\%).

At the same time, staff shortages are not a critical problem for the research participants in the development of their activities. The experts name a shortage of financial resources, difficulties in raising external financing, as well as a shortage of professional personnel as the main obstacles to the growth of the innovative activities of the population and SMEs (Figure 10). 


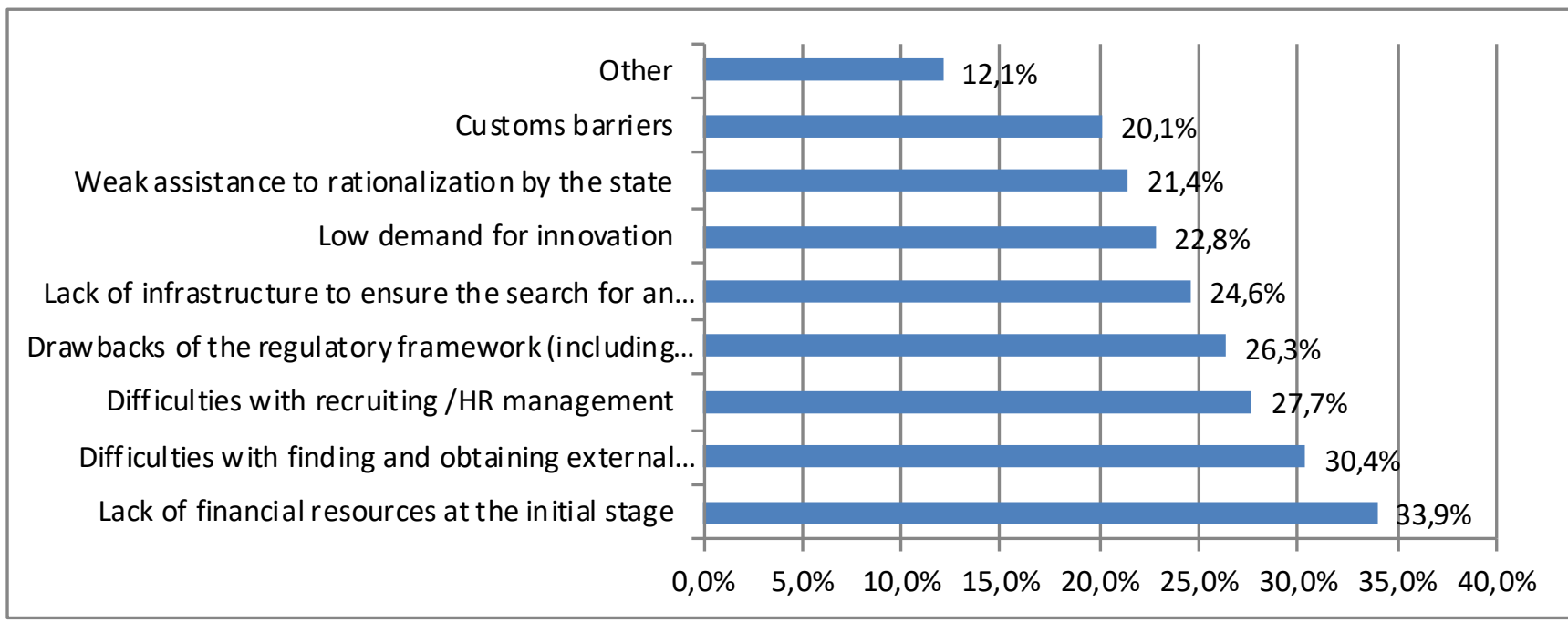

Figure 10. Barriers to increase innovative activities, $\%$ of the respondents

The analysis of expert opinions indicates that the relevance of barriers depends on the stage of development of an innovative product and/or technology.

For example, the main problems at the startup stage are the lack of funding and the difficulties of translating the idea into a product and the difficulty of obtaining external financing. More mature enterprises are more likely to experience difficulties associated with business growth, staff shortages, and the organization of internal processes.

\section{Discussion}

The results of the study reveal that many aspects of the development of innovative ecosystems in Russia, Belarus, and Kazakhstan are quite similar and generally do not correspond to the scientific and technological potential. The development of innovative SMEs in the three countries has common problems: the limited access to financing, the low motivation for innovative activities, and the lack of personnel with the necessary level of education and experience. This is generally consistent with the results of studies on entrepreneurship issues (Biryukov, et. al. 2020; Suglobov, et.al. 2020; Dudin et al. 2020; Krasnov, et. al. 2019). However, attention should be paid to some important issues.

The vast majority of the experts $(89.7 \%)$ expressed the view that the development of innovative entrepreneurship depended on the efficient measures aimed at encouraging the inventive activities of the population and at creating favorable conditions to reduce the shortage of professional and experienced personnel in innovative companies.

Three quarters of the experts agree that financial support measures for inventors and tax incentives are the main incentives for innovative activities (Figure 11). 
ENTREPRENEURSHIP AND SUSTAINABILITY ISSUES

ISSN 2345-0282 (online) http://jssidoi.org/jesi/

2020 Volume 8 Number 2 (December)

http://doi.org/10.9770/jesi.2020.8.2(13)

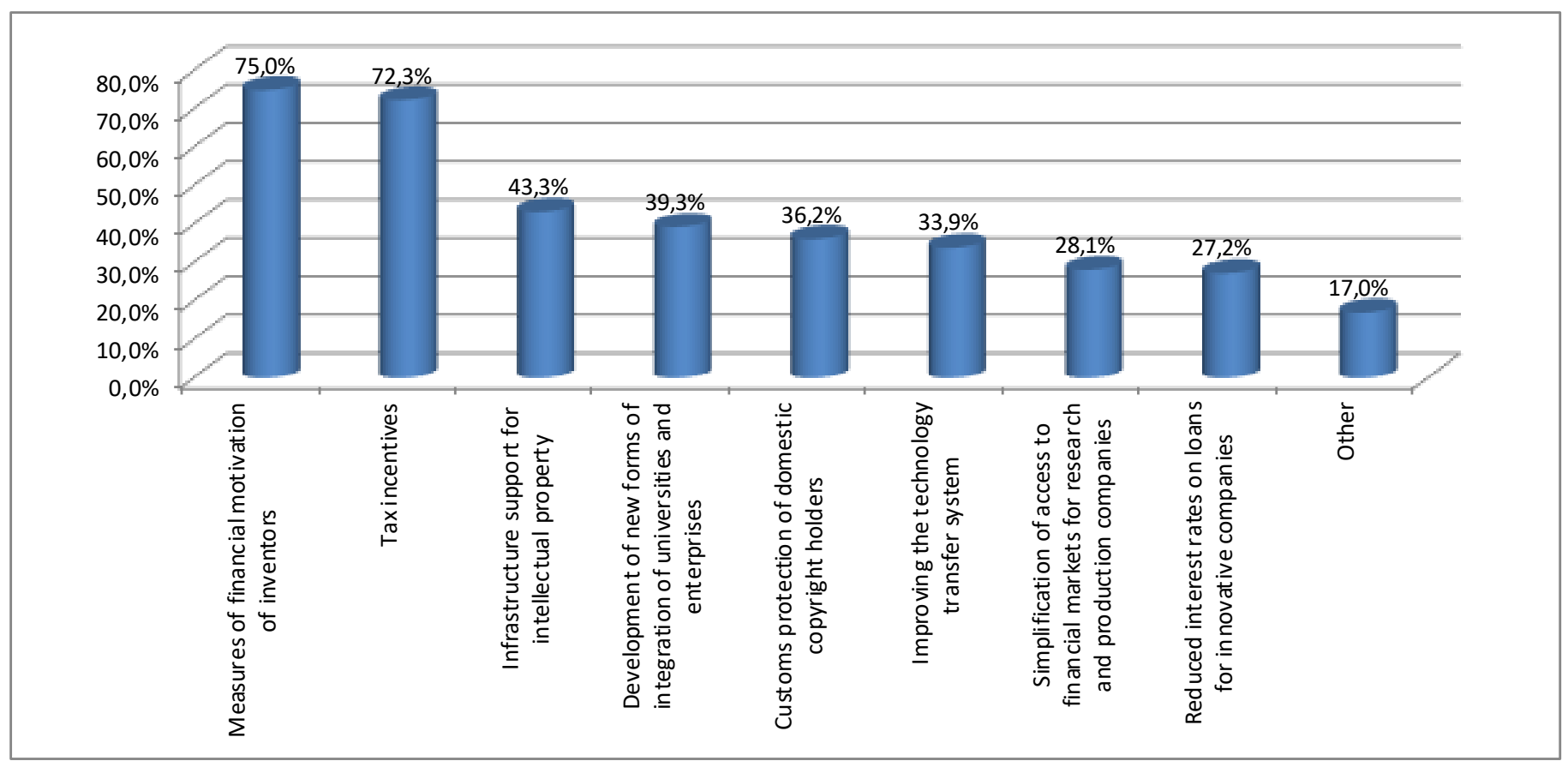

Figure 11. Incentives for innovative activities of the population, $\%$

The experts name the need for legislative consolidation of the responsibility of employers for the late payment of remuneration to the inventors, as well as establishing minimum amounts for paying for the creation of intellectual property results as the priority measures aimed at enhancing the financial motivation of inventors (Figure 12). 


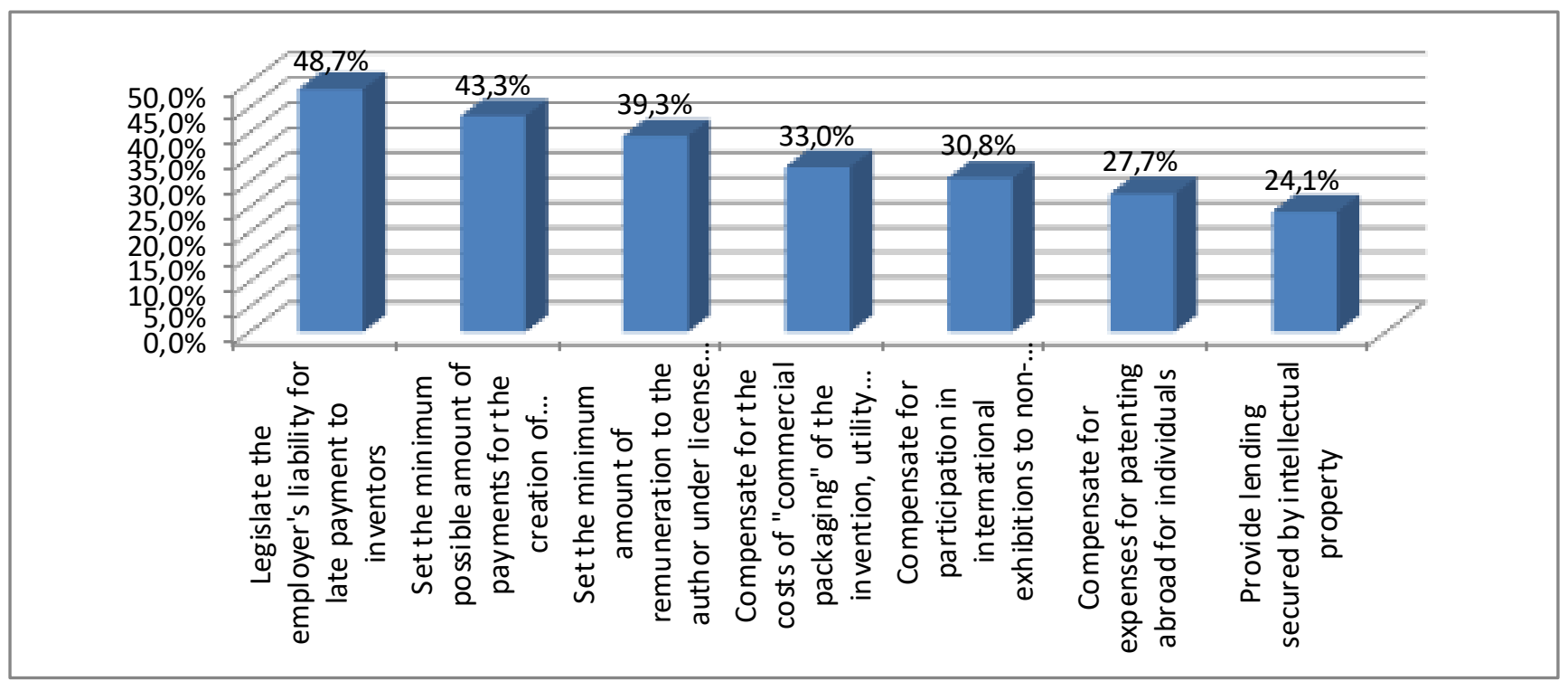

Figure 12. Priority measures to enhance the financial motivation of inventors

The rules for the payment of remuneration to the authors of employee inventions, utility models, and industrial designs are currently established at the legislative level in the countries under study. However, the need to conclude special agreements and the lack of responsibility for nonpayment of such remuneration established at the legislative level discourage employees of universities, research institutes, and innovative companies.

In the course of the interview, the experts proposed introducing standards into national laws providing for the procedure for paying remuneration for the creation of intellectual property results and the commercialization of inventions, models, and industrial designs.

About half of the experts $(48.7 \%$ ) consider it necessary to consolidate the responsibility of employers for the late payment of remuneration to the inventors at the legislative level, and $43.3 \%$ of the respondents spoke in favor of setting the minimum amount of payments for creating the intellectual activity results. About $39.3 \%$ of the respondents note the possibility of establishing the minimum amount of remuneration to the author or the team of authors in the event of the conclusion of a licensing agreement between the employer and the third party for the right to use an employee invention.

A third of the experts surveyed (33\%) noted the need for a mechanism to offset the costs of "commercial packaging" of the invention. 
The mechanism of an innovative voucher can solve this problem. The experts proposed to study the innovate experience of the EU member states and to prepare the necessary regulatory framework in order to launch the mechanism for using innovative vouchers. Innovative vouchers provide firms with a financial incentive on a noncompetitive basis (as opposed to cooperative $R \& D$ grants) to introduce small-scale innovations by establishing links between the SMEs and the state research institutions. They serve the dual purpose of directly encouraging the exchange of knowledge and of building long-term relationships between the industry and the knowledge providers. Voucher schemes provide small amounts of the state subsidies to the SMEs to help them access external support to develop specific competencies. An analysis of international experience in applying voucher schemes suggests that they can help SMEs increase their innovative potential and overcome specific barriers to their development, such as risk aversion.

Slightly less than a third of the experts $(31.8 \%)$ note that there are no mechanisms allowing inventors to participate in exhibition and forum events abroad on favorable terms today. They offer to extend the mechanism of cost compensation for the participation in such events as measures of financial motivation.

About $27.7 \%$ of the experts believe that the rules for compensation for the costs for patenting abroad in force in the countries under consideration do not apply to individuals. They noted the need to include these rules in the program to support the export of intellectual property rights.

Almost a quarter of the experts $(24.1 \%)$ propose creating a mechanism similar to the deposit insurance system, which will allow banks to lend against intellectual property while insuring the risks in insurance companies.

Tax incentives were mentioned by $72.3 \%$ of the experts as a motivation for the development of innovative entrepreneurship. The experts propose the abolition of VAT, the introduction of a multiplier for the costs of patent services, tax exemptions for transactions with intellectual property rights, and the payment of compensation through taxation of the expenses for patenting abroad as the main tax incentives (Figure 13).

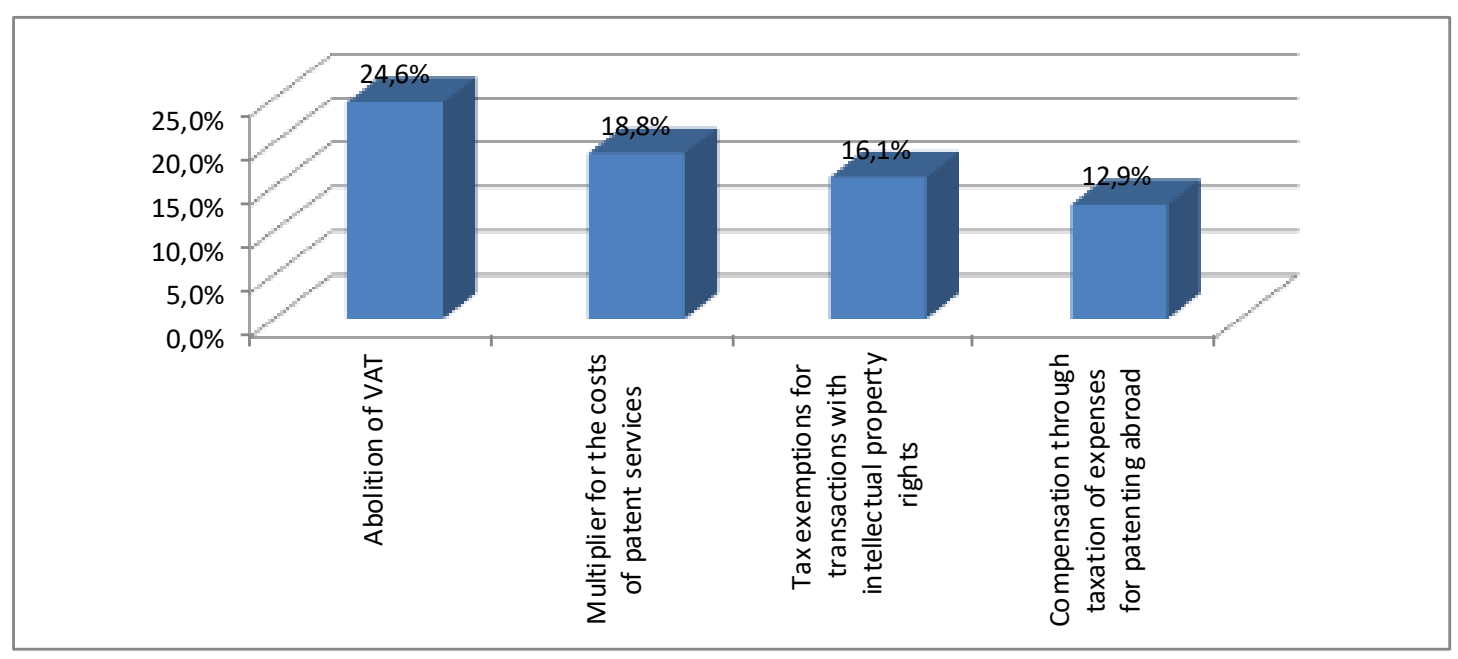


Figure 13. Tax incentive measures, $\%$ of the respondents

The existing VAT collection schemes in Russia, Belarus, and Kazakhstan create a barrier between the innovative SMEs and the large companies that require "input" VAT. The experts $(24.6 \%)$ made a proposal to replace VAT on products manufactured in the countries under study with sales tax. This will allow to transfer the tax burden to the retailer without budgetary losses as the final link in the production and sale chain.

Due to the postponed economic effect of inventive activities, there are currently no patent services in the structure of many companies. About $18.8 \%$ of the respondents suggested that the costs associated with the maintenance of patent offices should be attributed to the production costs for income tax purposes.

More than $16 \%$ of the experts identified exemption from taxation on the transactions related to the payment of author's royalties, sale of rights under license agreements, and sale of exclusive rights to inventions as incentive measures.

The experts indicated infrastructure support for intellectual property (43.3\%), the development of new forms of integration of universities and industrial enterprises $(39.3 \%)$, customs protection of domestic copyright holders $(36.2 \%)$, and improving the technology transfer system (33.9\%) almost twice less often than the financial support for authors and tax incentives.

As such, it can be stated with great confidence that the application of the above incentive measures in combination with the efficient mechanisms for creating a market for new inventions will create favorable conditions for the development of entrepreneurship and forms of self-employment in innovative sectors of the economy.

\section{Conclusion}

The results obtained in the course of this study have confirmed the hypothesis and are an important step towards the formation of a comprehensive identification of the existing innovative landscape in the three countries of the EAEU integration association and the development of directions for its development.

Despite the available innovative potential, the level of innovative activities remains quite modest. The main barriers to the development of innovative entrepreneurship are the lack of financial resources, the unforeseen expenses, processes, etc., and difficulties in raising the external financing.

The main measures to encourage the innovative activities of the population in the EAEU member states include financial incentives for inventors, tax incentives, infrastructural support for intellectual property results, development of new forms of integration of universities and enterprises, customs protection of domestic copyright holders, and improvement of technology transfer systems. 


\section{ENTREPRENEURSHIP AND SUSTAINABILITY ISSUES}

ISSN 2345-0282 (online) http://jssidoi.org/jesi/

2020 Volume 8 Number 2 (December)

http://doi.org/10.9770/jesi.2020.8.2(13)

\section{References}

Acs, Z.J., Audretsch, D.B., Braunerhjelm, P. \& Carlsson, B. (2012). Growth and entrepreneurship. Small business Economics, 39(2), 289300. https://doi.org/10.1007/s11187-010-9307-2

Aloisi, A. \& De Stefano, V. (2020). Regulation and the future of work: The employment relationship as an innovation facilitator. International Labour Review. Retrieved from: https://www.scopus.com/inward/record.uri?eid=2-s2.05083464570\&doi=10.1111\%2filr.12160\&partnerID=40\&md5=af18faf7e8dd3efcb942dfb39d28f38e

Aparicio, S., Urbano, D. \& Audrech D. (2016). Institutional factors, entrepreneurship opportunities, and economic growth: panel evidence data. Technological forecasting and social change, 102, 45-61. https://doi.org/10.1016/j.techfore.2015.04.006

Baumol, W.J. (2010). The Microtheory of Innovative Entrepreneurship, Princeton: Princeton University Press, pp. 246.

Bertoni, F., D'add, D. \& Grilli, L. (2019). Independent choice of entrepreneurial firms in thin venture capital markets: theory and empirical data. Journal of strategic entrepreneurship, 13(1), 47-74.

Biryuko, V.V., Dmitrieva, O.V., Frolova, V.B., Nikandrova L.K. \& Arkhipov, A.B. (2020). Formation of a Tourism Entrepreneurial Environment in the Conditions of Competition. Journal of Environmental Management and Tourism, 10(8), 1779-1784.

Bushueva, L.I., Popova, Y.F. \& Shikverdiev, P.A. (2020). Factor analysis of administrative barriers to entrepreneurial activities. Revista Inclusiones, 7(2), 242-254.

Castaño, M.-S., Méndez, M.-T. \& Galindo, M.-Á. (2015). The effect of social, cultural, and economic factors on entrepreneurship. Journal of Business Research, 68(7), 1496-1500. https://doi.org/10.1016/j.jbusres.2015.01.040

Chen, Y., Cao, J., Zhang, Y., Liu, C. \& Zhou, B. (2018). Research on Value and Development Strategy of Innovative Entrepreneurship Education in Colleges and Universities of China. 2018 International Conference on Humanities and Advanced Education Technology (ICHAET 2018), pp. 8-14.

Colombo, M. G., Giannangeli, S. \& Grilli, L. (2013). Public subsidies and employment growth of high-tech startups: assessing the impact of selective and automatic support schemes. Industrial and Corporate Change, 22(5), article 37.

Cumming, D. J., Grilli, L. \& Murtina, S. (2017). Public and independent venture capital investments in Europe: analysis of companies ' performance. Journal of Corporate Finance, 42, 439-459. https://doi.org/10.1016/j.jcorpfin.2014.10.016

Danilina, E., Malikova, I. \& Gorelov, D. (2020). Financing and support of employees of bankrupt companies in transport sector at municipal and state levels: national and international practice. Amazonia Investiga, 9(25), $135 \quad-142$. https://amazoniainvestiga.info/index.php/amazonia/article/view/1038

De la Hoz-Rosales B., Camacho Ballesta J. \& Tamayo Torres I. (2019). Effects of innovative entrepreneurship and the information society on social progress: An international analysis. Entrepreneurship and Sustainability Issues, 7(2), 782-813. https://doi.org/10.9770/jesi.2019.7.2(1)

Dudin, M. N., Shakhov, O. F., Ivashchenko, N. P. \& Shakhova, M. S. (2020). Development of entrepreneurial competencies in the economy (evidence from digital entrepreneurship). Revista Inclusiones, 7, 54-68.

Dudin, M. N., Shakhov, O. F., Vysotskaya, N. V. \& Stepanova, D. I. (2020). Public and Private Partnership: Innovation-Driven Growth of Agriculture at the Regional Level. Journal of Environmental Management and Tourism, 10(7), 1435-1444.

Eurofound (2018), Nonstandard forms of employment: Recent trends and future prospects, Eurofound, Dublin. 


\section{ENTREPRENEURSHIP AND SUSTAINABILITY ISSUES}

ISSN 2345-0282 (online) http://jssidoi.org/jesi/

2020 Volume 8 Number 2 (December)

http://doi.org/10.9770/jesi.2020.8.2(13)

Eurostat. (2020a) Domestic R\&D expenditure (GERD) by activity sector. Retrieved from: https://stats.oecd.org/Index.aspx?DataSetCode=GERD_TORD

Eurostat. (2020b). Domestic expenditure on R\&D (exploration), by sectors of performance. Retrieved from: https://stats.oecd.org/Index.aspx?DataSetCode=GERD_SEO

Eurostat. (2020c) R \& d personnel by industry, occupation and gender. Retrieved from: https://stats.oecd.org/Index.aspx?DataSetCode=PERS_OCCUP

Galindo M.-A., Méndez-Picazo M.-T. (2013). Innovation, entrepreneurship and economic growth. Management Decision, 51(3), 501-514. https://doi.org/10.1108/00251741311309625

Giraudo, E., Giudici, G. \& Grilli, L. (2019). Entrepreneurship policy and the financing of young innovative companies: Evidence from the Italian Startup Act. Research Policy, 48(9), 103801.

Giudicic, G., Gerini, M. \& Rossi-Lamastra, S. (2018). Crowdfunding of entrepreneurial projects based on remuneration: the impact of local altruism and localized social capital on the success of initiators. Small business Economics, 50(2), 307-324.

Grilli, L., Mazzucato, M., Meoli, M. \& Skellato, G. (2018). Sowing the seeds of the future: the policy of financing tomorrow's innovations. Technological forecasting and social change, 127, 1-7.

Grilli, L., Mrkadzic, B. \& Latifi, G. (2018). Venture capital in Europe: social capital, formal institutions and mediation effects. Small business Economics, 51(2), 393-410.

Karshalova, A.D., Markhayeva, B., Aitkazina, M.A. \& Mukushev, A. (2017). Improvement of management accounting in the context of uncertainty and risks in the food retailing sector in the Republic of Kazakhstan. Journal of Applied Economic Sciences, XII, Winter $8(54), 2275-2282$.

Kirchhoff, B.A., Newbert, S.L., Hasan, I. \& Armington, C. (2007). The influence of University R\&D expenditures on new business formations and employment growth. Entrepreneurship: Theory and Practice, 31(4), 543-559.

Klyver, K., Hunter, E., Watne, T. (2012). Entrepreneurial ties and innovativeness in the start-up decision. International Journal of Entrepreneurship and Innovation, 13(3), 153-163. https://doi.org/10.5367/ijei.2012.0084

Krasnov, A., Beknazarov, B., Jarikbayeva, D., Yeshpanova, D. \& Karshalova, A. (2019). Security of the Eurasian economic union member states: socioeconomic and financial aspects. Journal of Security and Sustainability Issues, 9(2), 637-648. https://doi.org/10.9770/jssi.2019.9.2(21)

Kumar, M. (2019). Global environmental policies with innovation spillovers. Management of Environmental Quality: An International Journal, 30(4), 833-850. https://www.emerald.com/insight/content/doi/10.1108/MEQ-05-2018-0098/full/html

Laužikas, M., Miliūtè, A. 2020. Liaisons between culture and innovation: comparative analysis of South Korean and Lithuanian IT companies. Insights into Regional Development, 2(2), 523-537. https://doi.org/10.9770/IRD.2020.2.2(2)

Lee, W.-L., Hsieh, C.-T. \& Huang, J.-C. (2020). Innovative Entrepreneurship Education of Computer Discipline in Colleges and Universities. Lecture Notes in Electrical Engineering, 551, 699-704. https://doi.org/10.1007/978-981-15-3250-4_88

Li N., Samin, H. \& Cowling, M. (2015). Access to Finance for innovative SMEs after the financial crisis. Research policy, 44(2), 370-380.

Lucchese, M. \& Pianta, M. (2012). Innovation and employment in economic cycles. Comparative Economic Studies, 54(2), 341-359.

Mas-Tu, A. \& Simón Moya, V. (2015). Young innovative companies (Yic) and entrepreneurship policy. Journal of Business Research, 68 (7), 1432-1435. https://doi.org/10.1016/j.jbusres.2015.01.028 


\section{ENTREPRENEURSHIP AND SUSTAINABILITY ISSUES}

ISSN 2345-0282 (online) http://jssidoi.org/jesi/

2020 Volume 8 Number 2 (December)

http://doi.org/10.9770/jesi.2020.8.2(13)

Mohd, Rosli, M. \& Syamsuriana, Sidek. (2013). The Impact of Innovation on the Performance of Small and Medium Manufacturing Enterprises: Evidence from Malaysia. Journal of Innovation Management in Small \& Medium Enterprise, 1-16. https://doi.org/10.5171/2013.885666

Muraya, E. N., Roganov ,V. R., Skiteva, E. I., Evgrafova, I. V. \& Daudov, I. L. (2019). Digital Entrepreneurship and Education: Support for Innovative Projects. International Journal of Advanced Trends in Computer Science and Engineering, 8(6), 3304-3311.

National Statistical Committee of the Republic of Belarus. Indicators of the European Innovation Scoreboard (EIS-2018) for the Republic of Belarus. Retrieved from: https://www.belstat.gov.by/ofitsialnaya-statistika/realny-sector-ekonomiki/nauka-i-innovatsii/

OECD, based on the 2019 OECD survey of national innovation statistics and the Eurostat's Community Innovation Survey (CIS-2016), Retrieved from: http://oe.cd/inno-stats, January 2020.

On the innovative activities of enterprises in the Republic of Kazakhstan. (2018). Statistics Committee of the Ministry of National Economy of the Republic of Kazakhstan. Retrieved from: https://stat.gov.kz/api/getFile/?docId=ESTAT307225

Orlova, N.A. (2017). Nonstandard forms of employment and changes in human capital: Analysis of the unskilled labor migration to Russia (2017) Monitoring Obshchestvennogo Mneniya: Ekonomicheskie i Sotsial'nye Peremeny, 1(137), 156-170.

Patent Index 2019. Retrieved from: https://www.epo.org/index.html https://www.epo.org/index.html

Ruchkina, G., Melnichuk, M., Frumina, S. \& Mentel, G. (2017). Small and medium enterprises in the context of regional development and innovations. Journal of International Studies, 10(4), 259-271.

Saiz-Álvarez, J.M., Cuervo-Arango, C. \& Coduras, A. (2013). Entrepreneurial strategy, innovation, and cognitive capabilities: What role for intuitive smes? Journal of Small Business Strategy, 23(2), 29-40.

Serrano, F., \& Altuzarra, A. (2010). Firms innovation activity and numerical flexibility. Industrial and Labor Relations Review, 63(2), 327339.

Suglobov, A. E., Repushevskaya, O. A., Tkach, A. V., Dashkov, L. P. \& Balalova, E. I. (2020). E-Commerce development prospects in the enterpreneurship of the Russian Federation. Revista Inclusiones, 7, 342-349.

The Global Innovation Index (2019). Creating Healthy Lives-The Future of Medical Innovation. Cornell University, INSEAD, and the World Intellectual Property Organization, from: https://www.globalinnovationindex.org/Download.aspx?file=/userfiles/file/reportpdf/gii-full-report-2019.pdf

Velilla, J. \& Ortega, R. (2020). Providing new products by innovative entrepreneurs in Europe. Economics and Business Letters, 9(2), 9096. https://doi.org/10.17811/ebl.9.2.2020.90-96

Wang, S., Wang, L., Xu, Q., \& Zhu, Y. (2019). Rival Absorptive Capacity and Innovation Performance of an Enterprise: The Moderating Effect of Dual Appropriability Mechanisms. Transformations in Business \& Economics, 18(3C (48C)), 565-579.

\section{Bakyt BEKNAZAROV}

ORCID ID: https://orcid.org/0000-0002-0518-2398

Roza NIYAZBEKOVA

ORCID ID: https://orcid.org/0000-0001-6666-0456

\section{Ussen AMIRSEITOV}

ORCID ID: https://orcid.org/0000-0002-6051-7496 


\section{ENTREPRENEURSHIP AND SUSTAINABILITY ISSUES}

ISSN 2345-0282 (online) http://jssidoi.org/jesi/

2020 Volume 8 Number 2 (December)

http://doi.org/10.9770/jesi.2020.8.2(13)

\section{Aiganym KOKENOV}

ORCID ID: https://orcid.org/0000-0002-7933-9247

\section{Marzhan DAURBAYEVA}

ORCID ID: https://orcid.org/0000-0001-7345-6648

\section{Madina AITKAZINA}

ORCID ID: https://orcid.org/0000-0002-8410-0900 